\title{
COOPERATION VS. COMPETITION. APPROACHES ON THE INCLUSION OF CHILDREN WITH SEN
}

\author{
Authors: \\ Nicoleta Ramona Ciobanu (Ph.D.) \\ University of Oradea (Romania)
}

Karla Melinda Barth (Ph.D.)

University of Oradea (Romania)

Maria Cristina Florescu (Ph.D.)

University of Oradea (Romania)

\author{
Lectors: \\ Laura Bochiș (Ph.D.) \\ University of Oradea (Romania) \\ Mihaela Indrieș (Ph.D.) \\ University of Oradea (Romania)
}

E-mail address of the first author:

nicoletaramona.ciobanu@yahoo.com

Ciobanu, Nicoleta Ramona; Barth, Karla Melinda \& Florescu, Maria Cristina (2021). Cooperation vs. Competition. Approaches on the Inclusion of Children with SEN. Különleges Bánásmód, 7. (1). 25-33. DOI $\underline{10.18458 / \mathrm{KB} .2021 .1 .25}$

\begin{abstract}
Solving learning tasks, among students, is usually done in the context of an interaction based on competition or cooperation. Either of the two types of interaction - cooperation and competition - has different effects in terms of the students' mutual attitudes, the degree of involvement and the degree of participation in the performance of school tasks and individual school performance. The success of the school inclusion of students with the SEN implies the cooperation between all the factors involved in this process. Special education is a part of the Romanian education system and should support educational programs for pupils with SEN suitable for their harmonious development. We started in our research from the application of a questionnaire to which teachers from Bihor County responded. If, in the preceding article, this working instrument was applied to a number of 163 teachers from mass education, to mixed classes that had in their composition and children with special educational requirements, in this article we extract the data that we have collected from to a number of 63 teachers in special education. The questionnaire comprises a total of 46 items referring to the atmosphere of cooperation and competition, and comprises two parts. The first part includes questions regarding seniority in work, educational grade, age, number of the group of students they work with, etc.
\end{abstract}

Keywords: cooperation, competition, special education, school performance, coopetition

Discipline: pedagogy 


\section{Absztrakt \\ EGYÜTTMÜKÖDÉS VS. VERSENY. A SAJÁTOS NEVELÉSI IGÉNYÜ GYERMEKEK INKLÚZIÓJÁNAK MEGKÖZELÍTÉSEI}

A diákok között a tanulási feladat megoldása általában verseny vagy együttműködés alapú interakcióban történik. Mindkét típusú interakciónak, a versenynek és az együttműködésnek egyaránt, különböző hatása van a diákok közös attitúdjére, a bevonódás mélységére és iskolai feladata bemutatásában való részvétel mértékére, valamint az egyéni iskolai teljesítményre. A sajátos nevelési igényú gyermekek iskolai inklúziójának sikere magába foglalja a folyamatban részt vevő összes faktor közötti együttmúködést. A gyógypedagógia része a román oktatási rendszernek és támogatja a sajátos nevelési igényú tanulók nevelési programjait, melyek a tanulók harmonikus fejlődéséhez illeszkednek. Kutatásunkat kérdőív alkalmazásával kezdtük, melyet Bihar megyei pedagógusok töltöttek ki. Egy korábbi tanulmányunkban ezt a módszert 163 normál tantervú iskolákban, vegyes összetételú, sajátos nevelési igényú gyermeket is befogadó osztályokban tanító pedagógus bevonásával végeztük. Jelenlegi tanulmányunkban a 63 gyógypedagógustól származó adatainkat mutatjuk be. A kétrészes kérdőív összesen 46 itemet tartalmaz, melyek a verseny és az együttmúködés légkörére irányulnak. Az első rész a következő információkat tartalmazza pl. munkában töltött idő, iskolai végzettség, életkor, gyermekek száma a tanulócsoportban stb.

Kulcsszavak: együttmúködés, verseny, gyógypedagógia, iskolai teljesítmény, kooperáció

Diszciplína: pedagógia

\section{Introduction}

Solving learning tasks among students is used to occur in the context of an interaction based on competition or cooperation relationships. Either of the two types of interaction - cooperation and competition - has different effects in terms of the students' mutual attitudes, the degree of involvement and participation in the accomplishment of the school tasks and the individual school performances.

The researches carried out in this direction (Mead, 1937, Deutsch, 1949) highlight the advantages and disadvantages of these types of learning, the extent and the way in which they should be used in one school situation or another. Competition represents mutual rivalry or a "fight" between two or more persons to achieve an indivisible goal (Golu, 1974, p. 158). Competition is a motivational form of self-assertion, in which the individual competes with others for the attainment of a social situation or superiority, and cooperation is a socially oriented activity, in which the individual collaborates with others to achieve a common goal (Ausubel, 1981, p. 491).

Define the two opposite ways of relating learning in special education, born at least two questions that we have addressed with the start of this scientific approach.

1. What approach do we use in the class we teach: Competition learning or cooperative learning?

2. Which of these two concepts represents the ideal form in the learning activities?

Creating a balanced environment for the learning process, which helps students to learn effectively, involves in addition to the attention and support from the teachers and a psychological basis for 
developing critical thinking of students and developing relationship and development skills (Pascariu, 2018, p. 60).

We consider that there is no "perfect cooperation", but no "abolished competition" (idea proposed for the whole society, by the American scientist A. Kohn, 1992) in a human community.

\section{Cooperation vs. Competition}

The most common models of competition are competitions, the Olympics, sports competitions, national assessments, exams. The rewards for winning such a competition include diplomas, prizes, averages and high marks, a self-image in crescendo and not least in popularity.

There are a myriad of other factors that influence the competitive processes within schools, including: teacher expectations, size of school and class, school transitions, school efficiency, ethnicity, child's cultural experience, restrictive or elaborate language codes, emotional intelligence, etc. (R. Harwood, S. A. Miller, R. Vasta, 2010, p. 408). Cooperative learning develops social skills, conflict resolution skills, leadership skills and teamwork skills, and as a result of cooperative learning, students learn to understand and work with others who are different from themselves. The reverse of the medal, on the other hand, is that students become dependent on their teammates and lose the ability to work alone, and group projects can create resentment among its members. On the axis presented below, we can see that a state of cooperation can become a state of competition between student teams, which in turn can generate an imminent conflict state. Therefore, the thin thread that links cooperation to a conflictual state is a very thin one (Fig. 1).

Competition stimulates the individual's effort and productivity and prepares students for life, which is very competitive but can generate aggressive conflicts and behaviors, lack of communication among colleagues, unfair marginalization of some of them, amplify anxiety and fear of failure, cultivate selfishness. The characteristics mentioned above show that both learning through cooperation and learning through competition have advantages and disadvantages in the exclusive and individual application in the classroom. For this reason, the term "COOPETITION" appeared.

The coopetition is an American neologism, but also an ideology obtained from the theory of games (Fig. 2). Competition games are the ways in which synergy can be created through partnership with competitors. Drawing a parallel between the competing games and the didactic approach, we can summarize the fact that the combination of these two types of learning is the key to success in the modern pedagogical approach.

This new form of organization of the learning process tends to be one of the most used outside the borders of the country. When we talk about the education in Bihor County, we can say that the atmosphere is one of cooperation, which tends towards one of co-competition, using all the levers needed to implement this type of organization.

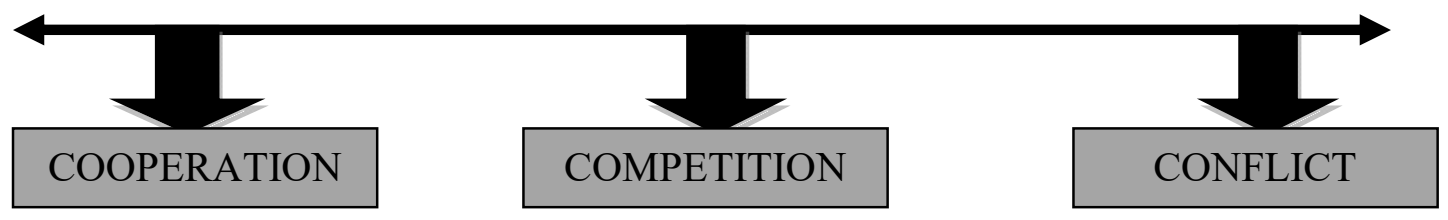


Figure 2. Representation of the term of coopetition. (Source:Authors)
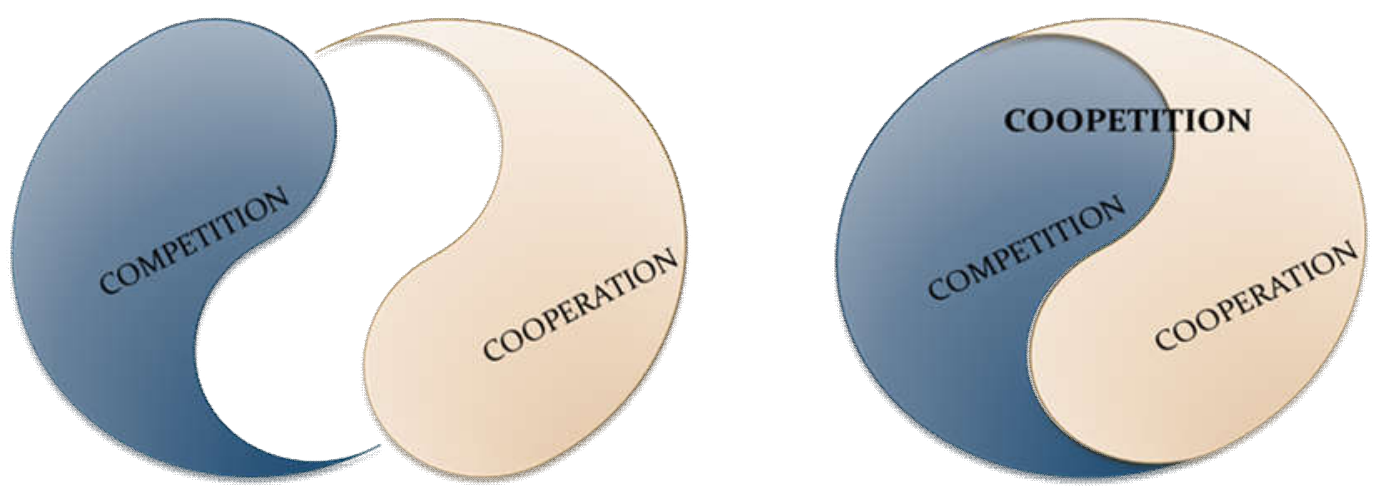

\section{Inclusion and cooperation}

For the success of the school inclusion, there is a need for cooperation between all the factors involved in this process. Special education is a component part of the Romanian education system and must support educational programs suitable for students with SEN for their harmonious development (Barth, Florescu, Ciobanu, 2019, p. 12). Children with special educational needs need support for adaptation, integration and socialization. From the point of view of Vygotsky (1978), a child with special needs who is integrated into an ordinary class could, through cooperation and interaction with his classmates, develop his knowledge, language and thinking, creativity and, no, last but not least, self-esteem.

To achieve this, it is necessary to adapt the contents, both quantitatively and qualitatively, to select objectives focused on their needs, to carry out school remediation programs, to adapt the teaching methods (learning methods through cooperation, active-participative methods, the didactic game), the didactic material (intuitive), of adapting the evaluation process, following the development of individual capacities, be they written, oral, visual, or kinesthetic.

Adherence to inclusive education highlights the need for school development, to properly meet the participation of children with disabilities (as well as other marginalized groups) in mainstream school environments, as component elements of human diversity - with its specific difference (Barth, Florescu, Ciobanu, The benefits of "coopetition" in the process teaching-learning assessment, in process of publication).

In the Figure 3, we represent the four types of education regarding the terms used to describe an educational program depending on child intellectual, social, cultural, personal and emotional development.

- Traditional education may be defined as a set of norms established by the traditional society. Many parents and teachers are concerned with maintaining the objective educational standards. In traditional education, the competition between pupils is cultivated with a view to their hierarchy and individual activity. 
- Special education is intended for all children with disabilities who fail to achieve a level of knowledge and social behaviour corresponding to their age in the ordinary education.

- Integrated education - involves relationships between individuals based on a recognition of their integrity, shared values and rights that they possess and aims to educate those children with special needs in ordinary schools alongside other normal children

- Inclusive education means that all children have access to quality education in an inclusive environment (Ciobanu, 2017, p. 36).

It is noteworthy that integrated education has produced a paradigm shift in the evaluation and intervention of the disabled child, with the emphasis being placed on psycho-pedagogical and sociological skills in school and social integration, thus overcoming the medical model. Any way the inclusion suits better to the need of children, because means more than comprehension, involves the elimination of discrimination and segregation, being a complex process involving all educational actors. (Ciobanu, 2017, p. 37)

\section{Methodology}

The research method used in this study is the survey method based on the questionnaire, having as working tools the questionnaire addressed to the teachers from Bihor County. It has been applied to a number of 63 teachers working in the special education system. The questionnaire comprises a total of 46 items referring to the atmosphere of cooperation and competition in the classes of special education, and the working instrument comprises two parts.

The first part includes questions related to seniority in work, educational grade, age, number of the group of students they work with, etc. The second part contains items that refer to the two types of educational approach (cooperation and competition). These items are in accordance with the present research and also with the way in which the teachers work in the special education institutions in Bihor County, Romania.

Figure 3. Comparison of types of education. (Source: Authors)
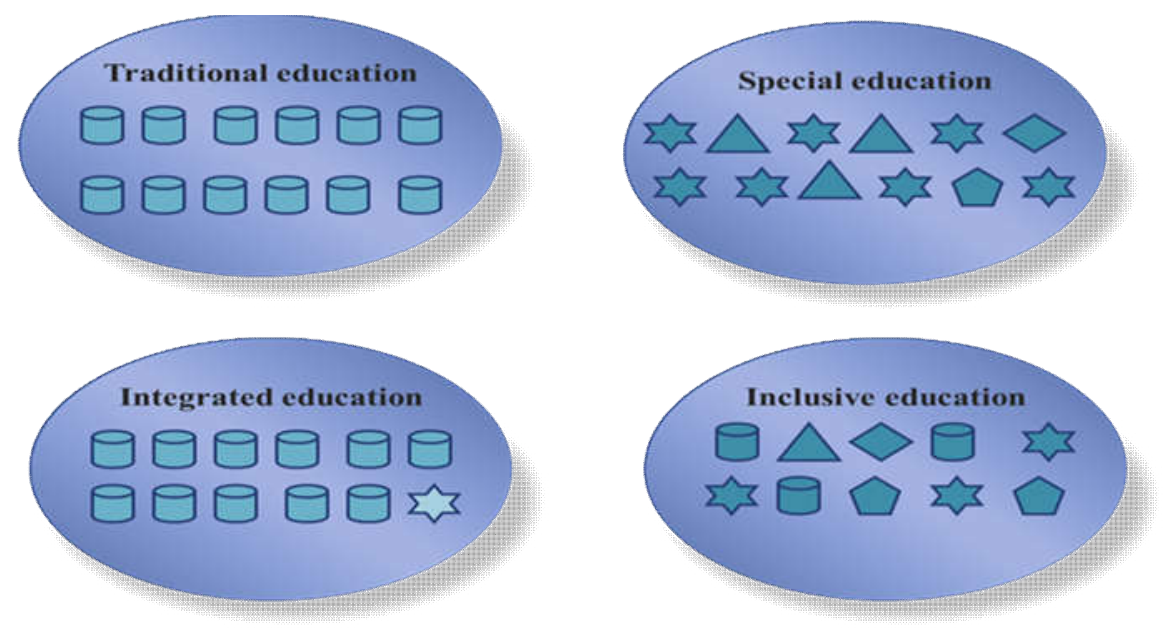
The research objectives were the following:

- Highlighting a possible correlation between the predominant atmosphere in the classroom and the success of a school success among children with SEN.

- The influence of the way of organizing the didactic activities and the school success of the students with special educational requirements.

The hypotheses_from which we started in this scientific endeavor were:

- the possibility of the success of the students with SEN if the classroom atmosphere is a cooperative one.

- the didactic approach through cooperation, favors the positive attitudes of the students with special educational requirements, as compared to the learning act.

- Most of the respondents of our scientific approach are teachers with more than 10 years experience in the chair. Of these teachers, most use cooperative learning for more than 6 years, although the number of courses they attended varies on average between 1 and 4 courses / teacher. From the attached diagrams (Figure 4.) it can be observed that in the classes to which the questioned teachers are teaching, the existing atmosphere is both competition and cooperation. This aspect reveals that the fusion between these manifestations, or their balanced weight, is natural in the special education in Bihor County.

From the below attached diagrams (Figure 5.) it can be observed that in the classes to which the questioned teachers are teaching, the existing atmosphere is both competition and cooperation. This aspect reveals that the fusion between these manifestations, or their balanced weight, is natural in the special education in Bihor County.

Figure 4. Distribution of respondents based on experience in years. (Source:Authors)

\begin{tabular}{l|r|r|r|r}
\hline & Experience in years \\
\hline & Frequency & Percent & $\begin{array}{c}\text { Valid } \\
\text { Percent }\end{array}$ & $\begin{array}{c}\text { Cumulative } \\
\text { Percent }\end{array}$ \\
\hline $0-1$ & 1 & 1.6 & 1.6 & 1.6 \\
$2-5$ & 2 & 3.2 & 3.2 & 4.8 \\
$6-15$ & 18 & 28.6 & 28.6 & 33.3 \\
$16-24$ & 24 & 38.1 & 38.1 & 71.4 \\
above 25 & 18 & 28.6 & 28.6 & 100.0 \\
Total & 63 & 100.0 & 100.0 & \\
\hline
\end{tabular}

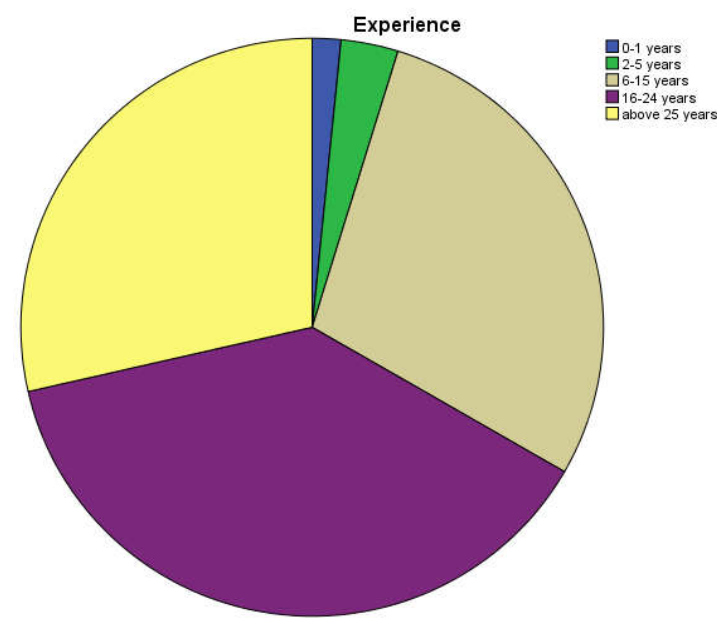


Figure 5. Competition end cooperation environement. (Source: Authors)
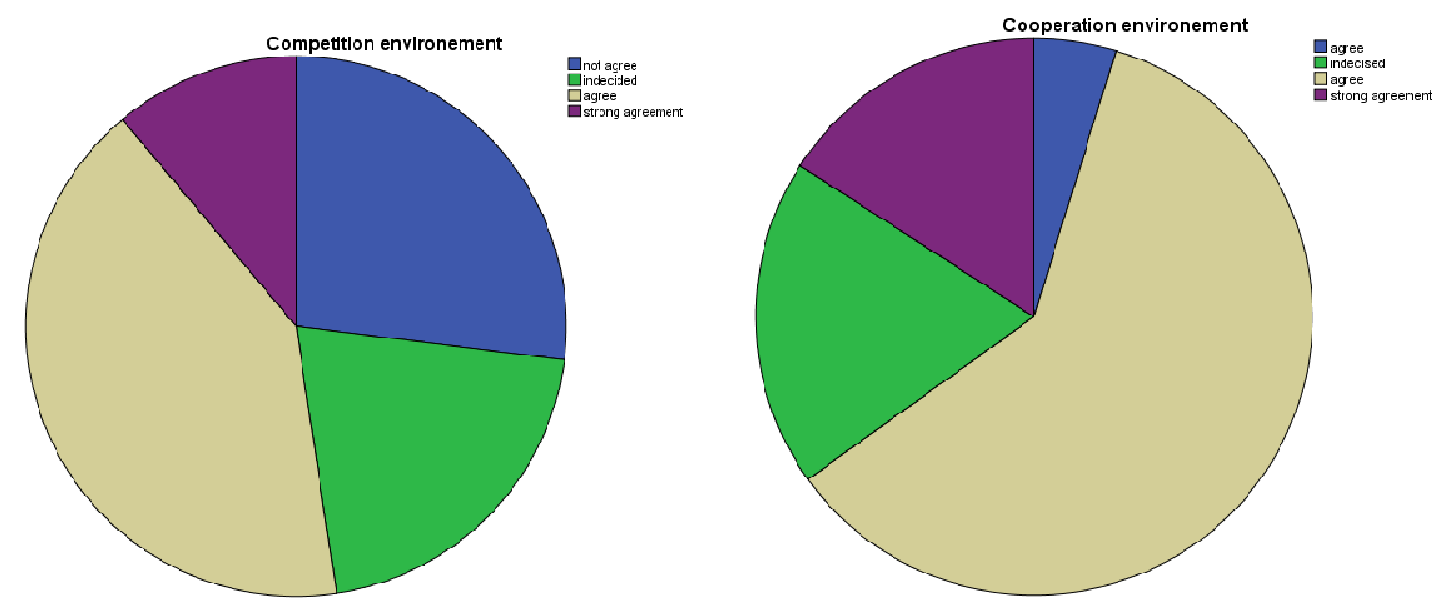

Figure 6. Collaborative learning is a valuable intsructional approach for children with SEN. (Source:Authors)

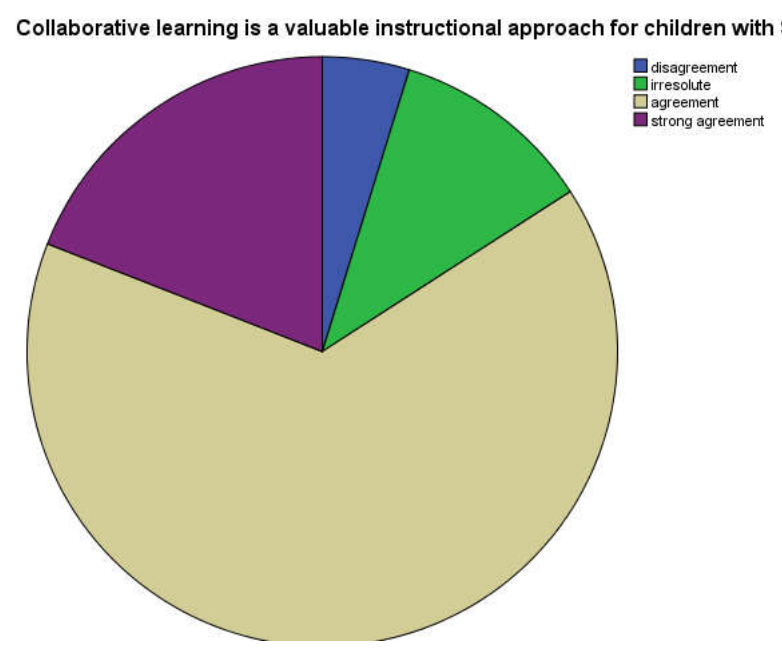

From the Figure 6, we find that more than half of those surveyed consider that the instructional approach through cooperation is beneficial to children with special educational requirements.

From the analyzed data it can be seen that learning through co-operation helps and stimulates children with SEN at the same time, and will also more easily accumulate the information taught in the classroom.

The importance of the cooperative environment in the classes with children with special requirements is very high, and the benefits of creating such a climate are essential in developing self-esteem.

The help offered to other colleagues and the response of others with the same measure ensures a conducive environment for effective learning. Carrying out the activities of learning, teaching and evaluation in the form of coopetition, not only facilitates the path to a cognitive development of children with learning difficulties, but also facilitates the path to communication with others. 
Figure 7. Peer interaction helps students with SEN to obtain a deeper understanding of the lessons. (Source:Authors)

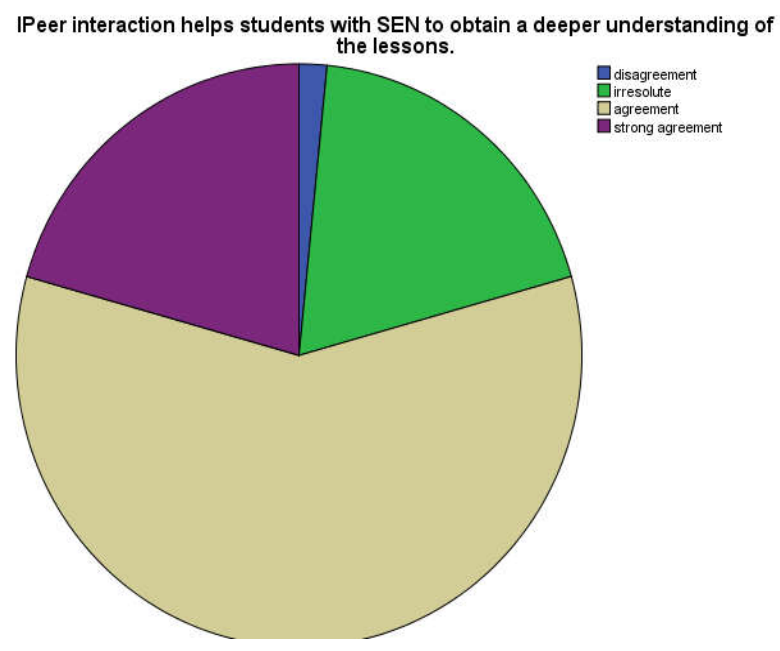

From the latest chart (Figure 7.) presented so far, we can argue that the implementation of learning through cooperation is not considered an obligation by the respondents; they prefer to use new teaching approaches, to the detriment of the traditional ones.

\section{Conclusions}

After analyzing the data, the two hypotheses from which we started in this approach, are confirmed. Therefore, we found that there is the possibility of easy inclusion of students with SEN if the classroom atmosphere is a cooperative one, and also that learning through cooperation is a valuable tool that favours the positive attitudes of the students towards the learning act. The data obtained by us highlight directions for the implementation of activities to raise awareness of the teaching staff regarding the importance of adopting a teaching style in accordance with the educational requirements imposed by the consistency of the class in which they teach.
In accordance with the data obtained and presented in this article, we consider it important to resize the didactic actions from the point of view of interdependence, and not of duality, between competition and cooperation, in order to streamline the educational-educational process and to optimize efficiency in different educational contexts. As a conclusion of the two instruments applied both in mainstream schools (Barth, Florescu, Ciobanu, The benefits of "coopetition" in the process teaching-learning assessment, in process of publication) and in inclusive education schools, we can say that the impact of coopetition is higher in children with special educational needs, but cooperation is more prevalent.

This type of approach helps children with special educational needs to manifest freely and unrestrained everything they know, to express certain feelings, to open themselves to effective communication, to develop their organizational skills. Also the cognitive, affective and creative development is an essential point in the use of coopetition, and this creates the lever for easy insertion in the society. 


\section{References}

Ausubel, D., \& Robinson, F. (1981). Learning in school. An introduction to pedagogical psychology. Holt, Rinehart és Winston.

Barth, Karla Melinda, Maria Cristina Florescu, and Nicoleta Ramona Ciobanu (2019). I also want to go to school... or the success of inclusive education depends on the attitude of the teachers. Romanian Journal of School Psychology 12.( 23). 7-16.

Ciobanu, N. R. (2017). Integrated education and inclusive education. Romanian Journal of School Psychology, 10(20), 35-39.

Deutsch, M. (1949). The theory of co-operation and competition. Human Relations, 2 (2), 129152. doi.10.1177/001872674900200204

Golu, P. (1974). Social psychology. Didactic and pedagogical publishing house. Bucureúti, Ed. Didactică úi pedagogică.

Harwood, R. L., Miller, S. A., Vasta, R., Manole, I., Avădani, I., \& Aneci, I. (2010). Child psychology. Polirom.

Johnson, D. W., \& Johnson, R. T. (1980). Integrating Handicapped students into the mainstream. Exceptional Children, 47 (2), 90-98. doi.10.1177/001440298004700202

Johnson, D. \& Johnson, R. (1998). Cooperative learning and social interdependence theory: Cooperative learning. www.cooperation.org/pages/SIT.html*

Kohn, A. (1992) No Contest The Case against Competition. Revised Edition, Houghton Mifflin Company, Boston, New York.

Mead, M. (1937), Co-operation and Competition Among Primitive Peoples. McGraw-Hill.

Pascariu, C. C. (2018). The conversion of general human values into competencies as a premise for teacher education. Education and Applied Didactics (EAD), 2(1), 59-68.

Vygotsky, L (1978). Mind in Society. Cambridge. Mass Harvard University Press.

Vygotsky, L. S. (1997). The collected works of LS Vygotsky: Problems of the theory and history of psychology (Vol. 3). Springer Science \& Business Media.

https://en.wikipedia.org/wiki/Coopetition (accessed 20.01.2020) 